\title{
HIPERTERMIJOS POVEIKIS ŽMOGAUS MOTORINEI SISTEMAI AKLIMACIJOS METU
}

\author{
Ieva Lukošiūtė-Stanikūnienė, Marius Brazaitis, Albertas Skurvydas, Soneta Ivanonė, \\ Dalia Mickevičienè, Irena Vitkienė \\ Lietuvos kūno kultūros akademija, Kaunas, Lietuva
}

\begin{abstract}
Ieva Lukošiūtė-Stanikūnienẻ. Biologijos mokslų magistrẻ. Lietuvos kūno kultūros akademijos biomedicinos krypties doktorantė. Moksliniu
\end{abstract} tyrimų kryptis — raumenų fiziologija: aklimatizacijos poveikis raumenų funkcijai.

\section{SANTRAUKA}

Tyrimo tikslas — nustatyti hipertermijos poveikižmogaus motorinei sistemai aklimacijos metu. Tiriamosios - sveikos fiziškai aktyvios moterys $(n=6)$. Ju amžius - 22,2 \pm 3,4 m., kūno masé - 63,93 $\pm 6,74 \mathrm{~kg}$, ūgis - 167,6 \pm 7,2 cm. Buvo atliekami du tyrimai - kontrolinis ir eksperimentinis. Tyrimas truko 14 dienu (7 kartus kas antra diena). Eksperimentinis tyrimas nuo kontrolinio skyrèsi tuo, kad jo metu vietoj pramankštos buvo pasyviai sukeliama hipertermija (tiriamosios 45 minutes sédèjo šiltoje vonioje, kurios vandens temperatūra $-44 \pm 1^{\circ} \mathrm{C}$ ). Išlipusios iš vonios, ne véliau kaip po 5 minučiu, tiriamosios buvo sodinamas i specialia dinamometro kèdę ir atliko 2 min trukmés maksimalu valinga izometrini raumenu susitraukima (MVJ-2 min). Ta patị krūvi atliko kontrolinè grupé. Keturgalvis šlaunies raumиo, 5 s maksimaliai valingai įtempus ji, 3 s buvo aktyvinamas elektriniu impulsu TT 100 Hz prieš šildyma, iš karto po izometrinio krūvio ir po 5 min. Be to, buvo nustatomas raumens valingo aktyvumo laipsnis.

Sukèlus hipertermija, rektalinè kūno temperatūra vidutiniškai padidèjo 2,08 $\pm 0,24^{\circ} \mathrm{C}(p<0,05)$. H-7 pradinè temperatūra buvo reikšmingai mažesnè $(p<0,05)$, palyginus su $H-1$ pradine. Viso tyrimo metu moterys vidutiniškai netekdavo apie: $H-1-0,63 \pm 0,12 \%, H-7-0,98 \pm 0,23 \%$ visos küno masès $(p<0,01)$. Tai rodo, kad septinta karta jos labiau prakaitavo, lyginant su pirmu tyrimu. Vertindami FSI (Fiziologinio streso indekso) kaita, kuri parodo širdies kraujagysliu (ŠSD) sistemos ir rektalinès temperatūros kaita, nustatème pastarojo reikšminga sumažejima septinto pasyvaus šildymo metu ( $<<0,05)$. FSI pirma aklimacijos dienq sieke 8,61 $\pm 1,17$ balu, septinta $-7,31 \pm 0,71$. Iki 35 šildymo minutès vidutiniai šiluminio pojūčio ir komforto vertinimo rodikliai padidejo: $H-1$ nuo šilta ir patogu iki nepakeliamai karšta ir labai nepatogu (p < 0,05), H-7 nuo šiek tiek šilta iki labai karšta ir nepatogu $(p<0,05)$. Tarp $H-1$ ir $\mathrm{H}-7$ reikšmingo skirtumo nenustatyta $(p>0,05)$.

Iš izometrinio raumenu susitraukimo jègos momento kitimo maksimalaus intensyvumo krūvio metu matyti, kad 3 krūvio sekundę jèga sumažèjo H-1 atveju, o 15 krūvio sekundę kontrolinès ir H-7 atveju $(p<0,05)$. Šis reikšmingas pokytis išliko iki 15 sekundžiu po krūvio. Praejjus 5 minutèms nuo krūvio pradžios raumenu izometrinio susitraukimo jèga grįzo ì pradini lygi ( $p>0,05)$. 15, 30, 45, 60, 75, 90, 105 ir 120 krūvio sekundę nustatytas reikšmingas izometrinio raumenu susitraukimo valingo aktyvavimo rodikliu skirtumas tarp $H-7$ ir kontrolines $(p<0,05)$, o 60, 75 ir 105 sekundę - tarp H-1 ir kontrolinès grupès rodikliu $(p<0,05)$.

Apibendrinant tyrimo rezultatus galima teigti, kad hipertermijos metu kylantis nuovargis gali atsirasti dèl dvieju pagrindiniu priežasčiu — raumenu lokaliu ir centrinès nervu sistemos pokyčiu.

Raktažodžiai: hipertermija, aklimacija, centrinis nuovargis, izometriniai pratimai.

\section{IVADAS}

$\mathrm{H}$ ipertermija yra apibūdinama padidejjusia žmogaus kūno temperatūra, kai nepajègiama pašalinti šilumos iš organizmo esant karštam ir drègnam orui, sunkiai dirbant fiziškai (Gonzalez-Alonso et al., 1999). Pakilus kūno temperatūrai, smegenims perduodami nerviniai impulsai, padideja prakaitavimas, suaktyvejja kraujo apykaitos procesas (Armstrong, Marech, 1991; Wilmore, Costill, 2004). Hipertermijos metu rektalinè kūno temperatūra gali pakilti iki $40^{\circ} \mathrm{C}$. Aukšta rektalinè temperatūra (didesnè kaip $40^{\circ} \mathrm{C}$ ) gali neigiamai paveikti centrinę nervų sistemą (CNS) ir šilumos išsiskyrimą iš organizmo (Kang et. al., 2003). Todèl hipertermija yra ribojantis veiksnys atliekant pratimus (MacDougall et a.1., 1974; Nielsen, 1992; Gonzalez-Alonso et al., 1999). Naujausi tyrimai parode, kad pasyvus kūno kaitinimas sumažina gebejjimą aktyvuoti griaučiu raumenis, netgi tuo atveju, kai nèra atliekamas joks fizinis darbas (Todd et al., 2005; Thomas et al., 2006). Temperatūros kaita gali tiesiogiai veikti raumenu valingą aktyvavima, nes temperatūra motoriniame vienete pakeičia impulso dažni, reikalingą tetaniniam susitraukimui. Padidejjus vidinei raumenu 
temperatūrai, atsipalaidavimo greitis išauga, ir tai gali sumažinti jẻgos išugdymo ar palaikymo dydi. Šiuo atveju didesnis motorinių vienetų aktyvavimo dažnis bus reikalingas norint palaikyti panašią jègą fizinio darbo metu, lyginant su raumeniu, kurio temperatūra yra žemesnè (Todd et al., 2005).

Atliekant fizinį krūvị hipertermijos sąlygomis, žmogaus organizmui gresia šiluminis stresas. Jo metu kūno temperatūra padidèja daugiau kaip $40^{\circ} \mathrm{C}$, žmogus nebeprakaituoja, oda pasidaro karšta ir sausa, padažnėja pulsas ir kvėpavimas, padidèja arterinis kraujospūdis, netenkama sąmonès (Kèvelaitis ir kt., 2002). S. S. Cheung (2007) pastebejjo, kad vienas svarbiausių ateities tyrimų aspektų, tiriant hipertermijos poveiki centriniam ir raumenų nuovargiui, yra testavimas ir vertinimas lyties požiūriu.

Vis dar trūksta tyrimų, kurių metu hipertermijos poveikis organizmui būtų nagrinėjamas ilgą laiką. Nepavyko aptikti ir tyrimų, nagrinejjančių aklimacijos poveiki motorinès sistemos darbingumui, atliekant fizinius pratimus hipertermijos sąlygomis.

Tyrimo tikslas - nustatyti hipertermijos poveikị žmogaus motorinei sistemai aklimacijos metu.

\section{TYRIMO METODAI}

Tiriamosios - sveikos fiziškai aktyvios moterys $(n=6)$. Jų amžius $-22,2 \pm 3,4$ m., kūno masè - 63,93 $\pm 6,74 \mathrm{~kg}$, ūgis - 167,6 $\pm 7,2 \mathrm{~cm}$. Jos buvo supažindintos su tyrimo tikslais, procedūra ir galimais nepatogumais. Norą dalyvauti tyrime moterys patvirtino raštu. Tyrimas atliktas laikantis $1975 \mathrm{~m}$. Helsinkio deklaracijoje priimtu principu dèl eksperimentų su žmonėmis etikos. Tyrimo protokolas aptartas ir patvirtintas Kauno regioniniame biomedicininių tyrimų etikos komitete (Protokolo Nr. 130/2005; Leidimo Nr. BE-2-54).

Dinamometrija. Izometrinè blauzdos tiesiamujų raumenų jèga vertinta naudojant izokinetini dinamometrą (Biodex Medical System 3, New York). Tiriamosios buvo sodinamos i dinamometro įrenginio kèdę, testuojama dešinè koja. Prie dinamometro pritvirtinamas papildomas blauzdos tvirtinimo itaisas. Kelio anatominè sąnario ašis nustatoma ir sulyginama su dinamometro dinaminès apkrovos mazgo ašimi. Nustatoma visa kelio sąnario amplitudè. Mažinant viso kūno inercinius svyravimus, tiriamoji apjuosiama pečių, liemens ir šlaunies diržais. Blauzda ịtvirtinama diržu virš kulnakaulio gumburo ties apatiniu trečdaliu, koja fiksuojama per kelio sąnari $90^{\circ}$ ir $120^{\circ} \mathrm{kampu}$, pasveriama tada, kai ji fiksuota $108^{\circ} \pm 5^{\circ} \mathrm{kampu}$ (veikia gravitacinè sunkio jèga). Valdymo skyde pasirenkamas izometrinis režimas.
Elektrostimuliavimas. Taikant tiesiogini elektrostimuliavimą, ant keturgalvio šlaunies raumens distalaus ir proksimalaus trečdalių dedami paviršiniai (geliu sutepti) guminiai elektrodai. Elektrodai sujungti su elektrostimuliatoriumi, imontuotu i elektromiografą Medicor MG440. Raumuo dirginamas stačiakampès formos elektriniu impulsu arba ju serija. Vienkartinio impulso trukmè - $1 \mathrm{~ms}$, stimuliavimo itampa parenkama individualiai, apie $85 \%$ maksimaliosios valingos jègos (MVJ). Elektrostimuliatoriaus siunčiamu dirgiklių impulsai registruojami Biodex Medical System personaliniame kompiuteryje. Keturgalvis šlaunies raumuo aktyvuojamas 1,10, d10, 20, 50, $100 \mathrm{~Hz}$ dažnio impulsais ir $5 \mathrm{~s}$ maksimaliai valingai įtempus raumeni $3 \mathrm{~s}$ TT $100 \mathrm{~Hz}$ prieš šildymą, iš karto po izometrinio krūvio ir po $5 \mathrm{~min}$.

Maksimaliosios valingos jègos 2 minučių krūvis (MVJ-2 min). Maksimalus valingas izometrinis krūvis truko 120 sekundžių. Kas 15 sekundžiu per odą elektriniu impulsu buvo stimuliuojamas šlaunies nervas naudojant aukštos ittampos stimuliatorių (modelis MG440, Medicor, Budapest, Hungry). Stimuliavimo trukmè $-250 \mathrm{~ms}$, dažnis $-100 \mathrm{~Hz}$, ittampos dydis - 85-105 V. Itampos dydis buvo parenkamas individualiai kiekvienai tiriamajai. Elektros stimuliavimo impulso itampa buvo didinama tol, kol nevalinga raumenu izometrinio susitraukimo jèga pasiekè $70-75 \%$ maksimaliosios jègos (stimuliacijos trukmè - $1 \mathrm{~s}$, dažnis - $100 \mathrm{~Hz})($ Nybo, Nielsen, 2001). Registravome maksimaliosios valingos jègos momentą $(\mathrm{N} \cdot \mathrm{m})$ ir raumenu valingo aktyvavimo laipsni VA\% = $($ maksimalioji valinga jèga $(\mathrm{MVJ})+$ elektrinis impulsas) / maksimalioji valinga jèga $(\mathrm{MVJ}) \times 100$, (kuo mažesnis VA\%, tuo aktyvavimo laipsnis didesnis, $100 \%$ rodo pilną raumenų aktyvavimas). Tiriamosios krūvio metu buvo motyvuojamos verbaliniu būdu, suteikiant joms vizualią jègos signalo kitimo informaciją.

Pasyvaus šildymo metodika. Tiriamosios sèdedamos 45 min kojas laike šiltoje vonioje, kurios vandens temperatūra $-44 \pm 1{ }^{\circ} \mathrm{C}$, kambario temperatūra $-20-24^{\circ} \mathrm{C}$ (1 pav.). Šildymo metu jos negalejo vartoti jokių gèrimų ar naudoti dirbtinio vėsinimo įrenginių. Šildymo pabaigoje testuojamo raumens temperatūra $3 \mathrm{~cm}$ gylyje padidèja $\sim 2,7^{\circ} \mathrm{C}$ (Sargeant, 1987; Ramanauskienè ir kt., 2006).

Dehidratacija. Tiriamosios prieš tyrimą ir po jo, būdamos nuogos ir nusišluosčiusios, pasveriamos elektroninemis svarstyklèmis „Tanita TBF 300" (Jungtinés Amerikos Valstijos). Nustatytas svorio skirtumas rodo skysčiu kieki, kurio jos 
neteko tyrimo metu. Tiriamosios tarp svėrimu negalejjo šlapintis ir vartoti skysčių.

Temperatūros matavimas. Rektalinè temperatūra buvo matuojama zondu, apvilktu silikonine guma su imontuotu termodavikliu (Ellab, tipas Rectal probe, Danija). Tiriamoji prieš pasyvų šildymą ir po jo isikišdavo zondą su termodavikliu i išeinamają angą (laikas - $10 \mathrm{~s}$, gylis $-12 \mathrm{~cm}$ ) (Proulx et al., 2003).

Odos temperatūra buvo matuojama prieš pasyvų šildymą ir po jo. Odos temperatūrai matuoti naudojamas paviršinis odos daviklis.

$$
\mathrm{T}_{\text {odos }}=0,5 \mathrm{~T}_{1}+0,36 \mathrm{~T}_{2}+0,14 \mathrm{~T}_{3} \text {, }
$$

čia T1 - nugaros; T2 - šlaunies; T3 - dilbio raumens temperatūra (Burton, 1935).

Vidutinẻ kūno temperatūra apskaičiuojama pagal formulę (Burton, 1935):

$$
\mathrm{T}_{\text {kūno }}=0,65 \mathrm{~T}_{\text {rektalinè }}+0,35 \mathrm{~T}_{\text {odos }}
$$

Šiluminio pojūčio ir komforto vertinimas. Šiluminis pojūtis ir komfortas buvo matuojamas raumenų šildymo metu. Kas 5 minutes tiriamosios turejjo įvertinti savo pojūčius nuo nepakeliamai šalta (0 balų) iki nepakeliamai karšta (10 balų), neutralu (5 balai) ir komforta — patogu (1 balas) ir ypač nepatogu (5 balai) (Gagge et al., 1967).

FSI matavimo metodika. Fiziologinio streso (šilumos) indeksas (FSI) buvo apskaičiuotas pagal formulę (Moran et al., 1998):

$$
\begin{gathered}
\mathrm{FSI}=5\left(\mathrm{~T}_{\text {rektaline } t}-\mathrm{T}_{\text {rektalinè } 0}\right) \times(39,5- \\
\left.\mathrm{T}_{\text {rektalinè } 0}\right)^{-1}+\left(\stackrel{\text { S SSD }}{t}-\breve{S S D}_{0}\right) \times\left(180-\mathrm{SSS}_{0}\right),
\end{gathered}
$$

čia $-T_{\text {rektalinè } 0}$ ir ŠSD 0 - pradiniai matavimai; $T_{\text {rektaliné } t}$ ir $\check{S}_{S} D_{t}$ - pasikartojantys matavimai per tam tikrą laiką.

FSI vertinimas: streso nèra arba labai mažas ( $0-2$ balai), mažas ( $3-4$ balai), vidutinis ( $5-6$ balai), didelis ( $7-8$ balai) ir labai didelis stresas (9-10 balu).

Matematinė statistika. Buvo apskaičiuojami rodikliu aritmetiniai vidurkiai ir standartiniai nuokrypiai. Analizuojamų rodiklių kaita priklausomai nuo raumenu temperatūros ir laiko kaitos buvo analizuojama taikant dviejų veiksnių dispersinę analizę. Skirtumas statistiškai reikšmingas, kai $p<0,05$.

Tyrimo eiga. Eksperimento eiga pirmą kartą aprašyta paralelinio $\mathrm{K}$. Vadopalo ir bendraautoriu atlikto tyrimo metu (2007). Prieš eksperimentą buvo atliekamas žvalgomasis tyrimas, kurio metu tiriamieji turejo priprasti prie laboratorijos aplinkos sąlygu ir pasimokyti atlikti didžiausio valingo raumenų izometrinio susitraukimo krūvị. Ne anksčiau kaip po savaitès tiriamieji, atrinkti atsitiktiniu būdu, atliko kontrolini arba eksperimentini tyrima.

Buvo atliekami du tyrimai: kontrolinis ( 7 kartus kas antrą dieną) ir eksperimentinis ( 7 kartus kas antrą dieną). Eksperimentinis tyrimas nuo kontrolinio skyressi tuo, kad jo metu vietoj pramankštos buvo pasyviai sukeliama hipertermija. Prieš tyrimą taikant pasyvią hipertermiją, tiriamosios atliko vieną krūvị ir ne vẻliau kaip prieš savaitę iki tyrimo - be pasyvios hipertermijos.

Taikant pasyvaus šildymo metodiką, tiriamosios, atvykusios i laboratorija, $30 \mathrm{~min}$ ramiai sédedavo iprastinès temperatūros kambaryje $\left(20-22^{\circ} \mathrm{C}\right)$. Paskui matuojama jų rektalinè temperatūra. Vèliau atliktas kontrolinis MVJ matavimas, t. y. darant 2 min pertrauką atlikti trys maksimalūs valingi raumenų susitraukimai tiesiant blauzdą per kelio sąnari $120^{\circ}$ fiksuotu kampu (raumenų susitraukimo trukmè - 5 s). Maždaug 2-3 šiu susitraukimu sekundę keturgalvis šlaunies raumuo buvo stimuliuojamas $100 \mathrm{~Hz}$ dažnio ir $250 \mathrm{~ms}$ trukmès elektrinių impulsų serija. Paskui taikomas pasyvus koju šildymas, iš karto po šildymo vèl buvo matuojama rektalinè temperatūra. Išlipus iš vonios, ne vèliau kaip po 5 minučiu, tiriamoji buvo sodinama i specialią dinamometro kẻdę ir atliko 2 min trukmès maksimalų valingą izometrinị raumenų susitraukimą (MVJ-2 min). Praejjus 15 ir 300 sekundžiu po krūvio - kontrolinis testavimas. Krūvio metu tiriamoji vilkèjo šiltą ilgą sportinę aprangą, buvo užsidejusi pirties kepuraitę (hipertermijai išlaikyti eksperimentiniu tyrimų metu). Abiejų eksperimentu pabaigoje buvo matuojama rektalinè temperatūra (hipertermijai kontroliuoti).

Kontrolinio tyrimo metu tiriamosios po neintensyvios pramankštos - 10 min bėgimo (pulso dažnis - 110 - 130 tv. / min) — buvo sodinamos i specialią izokinetinio dinamometro kèdę ir atliko testavimą pagal tą pati protokolą, tik be pasyvaus raumenų šildymo.

\section{REZULTATAI}

Nustatyta, kad tiek po pirmos aklimacijos dienos (H-1), tiek po septintos (H-7) rektalinè temperatūra po pasyvaus šildymo vidutiniškai padidèdavo apie $2^{\circ} \mathrm{C}(\mathrm{p}<0,05)$ (žr. 1 lent.). H-7 pradinè temperatūra buvo reikšmingai mažesnè $(p<0,05)$, palyginus su H-1 pradine temperatūra.

Tiriamosios viso tyrimo metu vidutiniškai netekdavo apie: $\mathrm{H}-1-0,63 \pm 0,12 \%, \mathrm{H}-7-$ $0,98 \pm 0,23 \%$ visos kūno masès $(\mathrm{p}<0,01)$. Tai rodo, kad jos septintą kartą labiau prakaitavo, lyginant su pirmu tyrimu.

Vertindami šiluminio streso indekso kaitą, kuri parodo širdies kraujagyslių ( ̌SSD) sistemos ir rektalinès temperatūros pokyčius, nustatytas pastarojo 
reikšmingas sumažèjimas septinto pasyvaus šildymo metu ( $\mathrm{p}<0,05)$ (2 pav.). Galima konstatuoti, kad vertinant sumini temperatūrų ir širdies kraujagyslių sistemos pokyti, pastebima aklimacija.

Pasyvaus šildymo metu tiriamosios kas penkias minutes turèjo įvertinti savo šilumini pojūtị ir komfortą. Nustatyta, kad iki 35 šildymo minutès vidutiniai šiluminio pojūčio ir komforto vertinimo rodikliai padidejo: $\mathrm{H}-1$ nuo šilta ir patogu iki nepakeliamai karšta ir labai nepatogu $(\mathrm{p}<0,05)$, H-7 - nuo šiek tiek šilta iki labai karšta ir nepatogu $(\mathrm{p}<0,05)$. Tarp H-1 ir H-7 rodiklių reikšmingo skirtumo nenustatyta $(\mathrm{p}>0,05)$.

Iš raumenų izometrinio susitraukimo jègos kitimo atliekant maksimalaus intensyvumo krūvị matyti (3 pav.), kad 3 krūvio sekundę jèga sumažèjo
$\mathrm{H}-1$ atveju, o 15 sekundę kontrolinès ir $\mathrm{H}-7$ atveju $(\mathrm{p}<0,05)$. Šis reikšmingas pokytis išliko $15 \mathrm{se}-$ kundžių po krūvio. Praejjus 5 minutėms nuo krūvio pabaigos, raumenu izometrinio susitraukimo jègos rodikliai grižo i pradini lygi $(p>0,05)$. Taip pat nustatytas reikšmingas raumenų izometrinio susitraukimo jègos skirtumas 15, 30, 45, 60, 75 ir 90 krūvio sekundę tarp H-7 ir kontrolinès ( $p<0,05)$, o 15 ir 75 sekundę - tarp H-1 ir kontrolinès grupès rodikliu $(\mathrm{p}<0,05)$. Tyrimo duomenys rodo, kad H-7 metu jèga buvo labiau sumažèjusi, lyginant su $\mathrm{H}-1$, nors pastarasis skirtumas ir nèra reikšmingas $(p>0,05)$. Tai rodo, kad septyni hipertermijos tyrimai tik pablogino maksimaliosios valingos jègos rodiklius.

Kontrolinès grupès tyrimo metu pastebèta, kad atliekant ta patị krūvị septynis kartus kas antrą
1 pav. Pasyvaus šildymo protokolas (modifikuota pagal Brazaitis ir kt., 2004)

Pastaba. $\circ$ - rektalinès ir odos paviršinès temperatūros matavimas; $\boldsymbol{\nabla}$ - širdies ir kraujagyslių sistemos rodikliu registravimas.

2 pav. Fiziologinio streso (šilumos) indekso rodikliai
Pastaba. \# - skirtumas reikšmingas, lyginant $\mathrm{H}-1$ su H-7 $(\mathrm{p}<0,05)$.
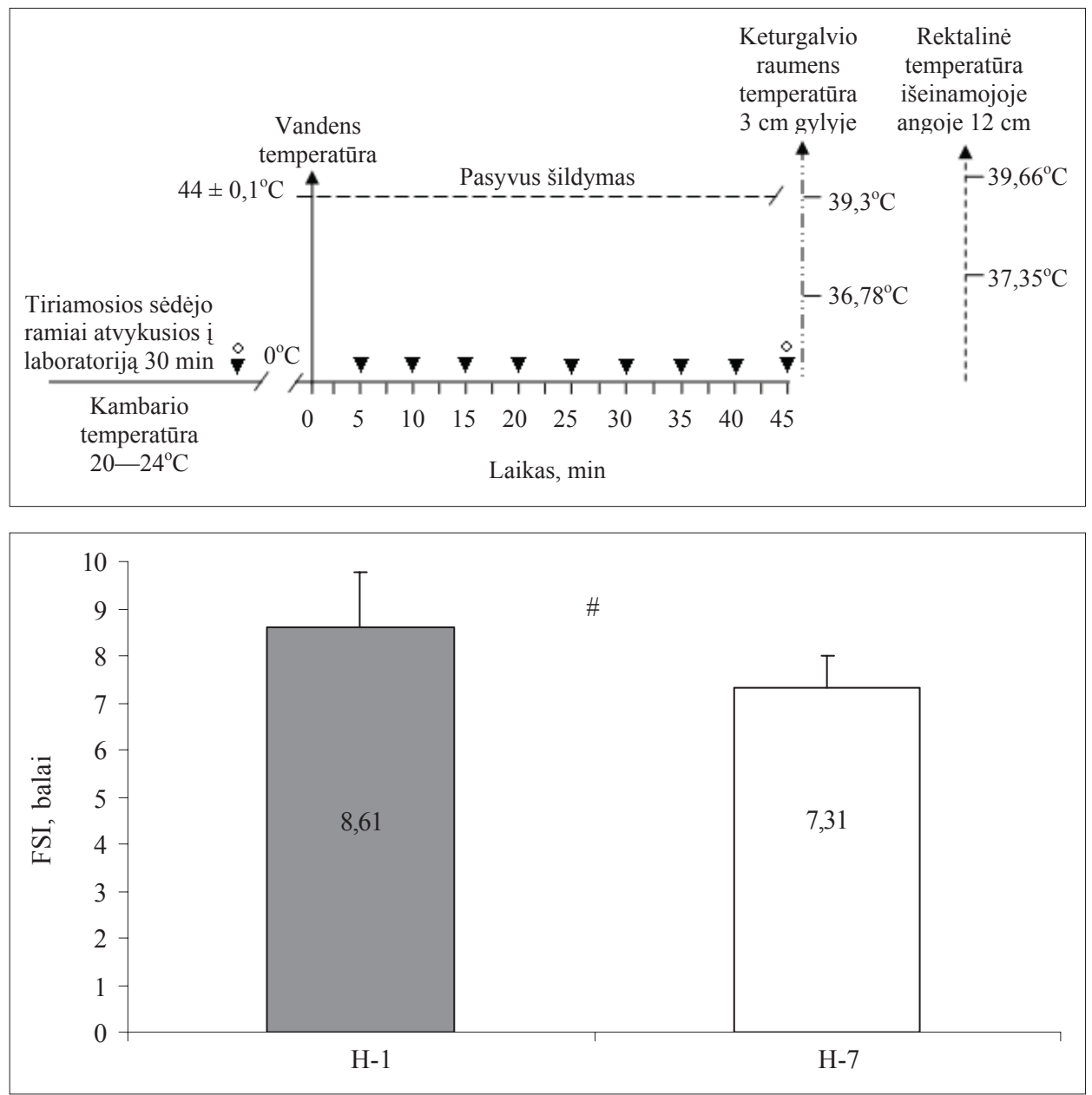

1 lentelè. Rektalinès, odos ir vidutinès kūno temperatūros skirtumas prieš pasyvų šildymą ir po jo

\begin{tabular}{|c|c|c|c|c|c|c|}
\hline \multirow{2}{*}{ Parametrai } & \multicolumn{3}{|c|}{ H-1 } & \multicolumn{3}{|c|}{ H-7 } \\
\hline & Prieš šildymą & Po šildymo & Skirtumas, \% & Prieš šildymą & Po šildymo & Skirtumas, \% \\
\hline $\mathrm{T}$ rektalinè,${ }^{\circ} \mathrm{C}$ & $37,53 \pm 0,2$ & $39,62 \pm 025$ & $0,93 \pm 0,49 *$ & $37,23 \pm 0,16$ & $39,25 \pm 0,3$ & $0,89 \% \pm 0,65 \% *$ \\
\hline $\mathrm{T}$ odos, ${ }^{\circ} \mathrm{C}$ & $33,48 \pm 0,9$ & $36,85 \pm 0,5$ & $10,12 \pm 2,15^{*}$ & $33,53 \pm 1,07$ & $36,83 \pm 0,4$ & $9,65 \pm 4,53 *$ \\
\hline T vidutinè kūno, ${ }^{\circ} \mathrm{C}$ & $36,11 \pm 0,31$ & $38,65 \pm 0,32$ & $7,03 \pm 1,16^{*}$ & $35,94 \pm 0,43$ & $38,36 \pm 0,30$ & $6,76 \pm 1,73^{*}$ \\
\hline
\end{tabular}

Pastaba. * ${ }^{*}$ - p $<0,05$, lyginant temperatūrą prieš pasyvų šildymą su temperatūra po jo. 
3 pav. Maksimaliosios valingos jègos rodikliai atliekant izometrini raumenų susitraukimą - tiesiant blauzdą per kelio sąnari fiksuotu $120^{\circ}$ kampu
Pastaba. * - (kontrolinis) $;$ - $(\mathrm{H}-$ 1); †-(H-7) — skirtumas reikšmingas, lyginant su pradiniais rodikliais \# - skirtumas reikšmingas tarp kontrolinio ir $\mathrm{H}-1$ rodiklio; $\neq-$ skirtumas reikšmingas tarp kontrolinio ir $\mathrm{H}-7$ rodiklio.

4 pav. Maksimaliosios valingos jègos rodikliai atliekant izometrinị raumenu susitraukima - tiesiant blauzdą per kelio sąnarị fiksuotu $120^{\circ}$ kampu
Pastaba. $\ddagger$ pirmas krūvis (IPR-1); $\dagger$ - septintas krūvis (IPR-7) — skirtumas reikšmingas, lyginant su pradiniais rodikliais. Reikšmingo skirtumo tarp IPR-1 ir IPR-7 krūvio rodiklių nebuvo.
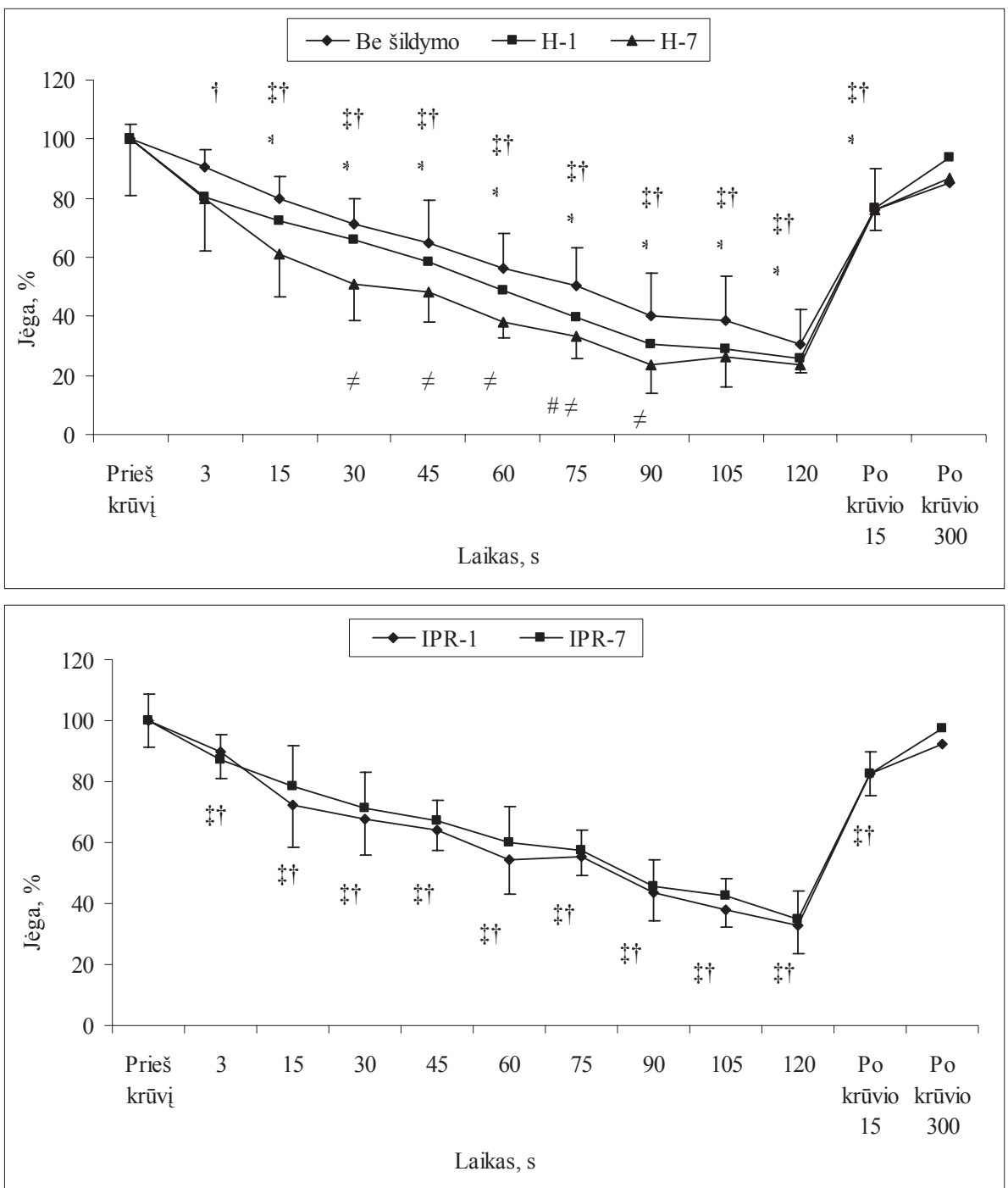

dieną tiriamujų keturgalvio šlaunies raumens jèga nepadidèjo. Iš raumenų izometrinio susitraukimo jègos kitimo maksimalaus intensyvumo krūvio metu matyti (4 pav.), kad 3 krūvio sekundę jèga sumažejo tiek pirmo tyrimo (IPR-1), tiek septinto tyrimo IPR-7 atveju $(p<0,05)$. Šis reikšmingas pokytis išliko iki 15 sekundžiu po krūvio. Praejjus 5 minutems nuo krūvio pabaigos, raumenų izometrinio susitraukimo jègos rodikliai grižo i pradini lygi $(\mathrm{p}>0,05)$.

Iš raumenų izometrinio susitraukimo valingo aktyvavimo kitimo maksimalaus intensyvumo krūvio metu matyti (5 pav.), kad 3 krūvio sekundę valingo aktyvavimo rodiklis sumažèjo reikšmingai H-1 atveju, 15 krūvio sekundę - H-7 atveju, o 30 krūvio sekundę - ir kontrolinio tyrimo metu $(\mathrm{p}<0,05)$. Šis reikšmingas pokytis išliko iki krūvio pabaigos. Praejjus 15 sekundžių ir 5 minutėms nuo krūvio pabaigos, raumenų izometrinio susitraukimo valingo aktyvavimo rodiklis grịzo i pradini lygi $(\mathrm{p}>0,05)$. Taip pat nustatytas reikšmingas raumenu izometrinio susitraukimo valingo aktyvavimo rodiklių skirtumas 15,30 , 45, 60, 75, 90, 105 ir 120 krūvio sekundę tarp H-7 ir kontrolinès $(p<0,05)$, o 60, 75 ir 105 sekundę tarp H-1 ir kontrolinès $(p<0,05)$. Tyrimo duomenys rodo, kad septinto tyrimo metu valingo aktyvavimo rodiklis, rodantis centrinio nuovargio dydị, buvo labiau sumažèjęs, lyginant su H-1, nors pastarasis skirtumas ir nèra reikšmingas $(p>0,05)$. Tai rodo, kad septyni hipertermijos tyrimai padidino centrini nuovargi ir aklimacija tam neturejo poveikio.

Iš kontrolinès grupès raumenų izometrinio susitraukimo valingo aktyvavimo kitimo maksimalaus intensyvumo krūvio metu matyti (6 pav.), kad 3 krūvio sekundę valingo aktyvavimo rodiklis sumažejo reikšmingai $(p<0,05)$ IPR-1 atveju. Šis reikšmingas pokytis išliko iki krūvio pabaigos. Praejjus 15 sekundžių ir 5 minutèms nuo krūvio pabaigos, raumenų izometrinio susitraukimo valingo aktyvavimo rodiklis grįzo i pradinị lygị. Septinto tyrimo metu (IPR-7) reikšmingo skirtumo, lyginant su pradiniais rodikliais, nebuvo. 

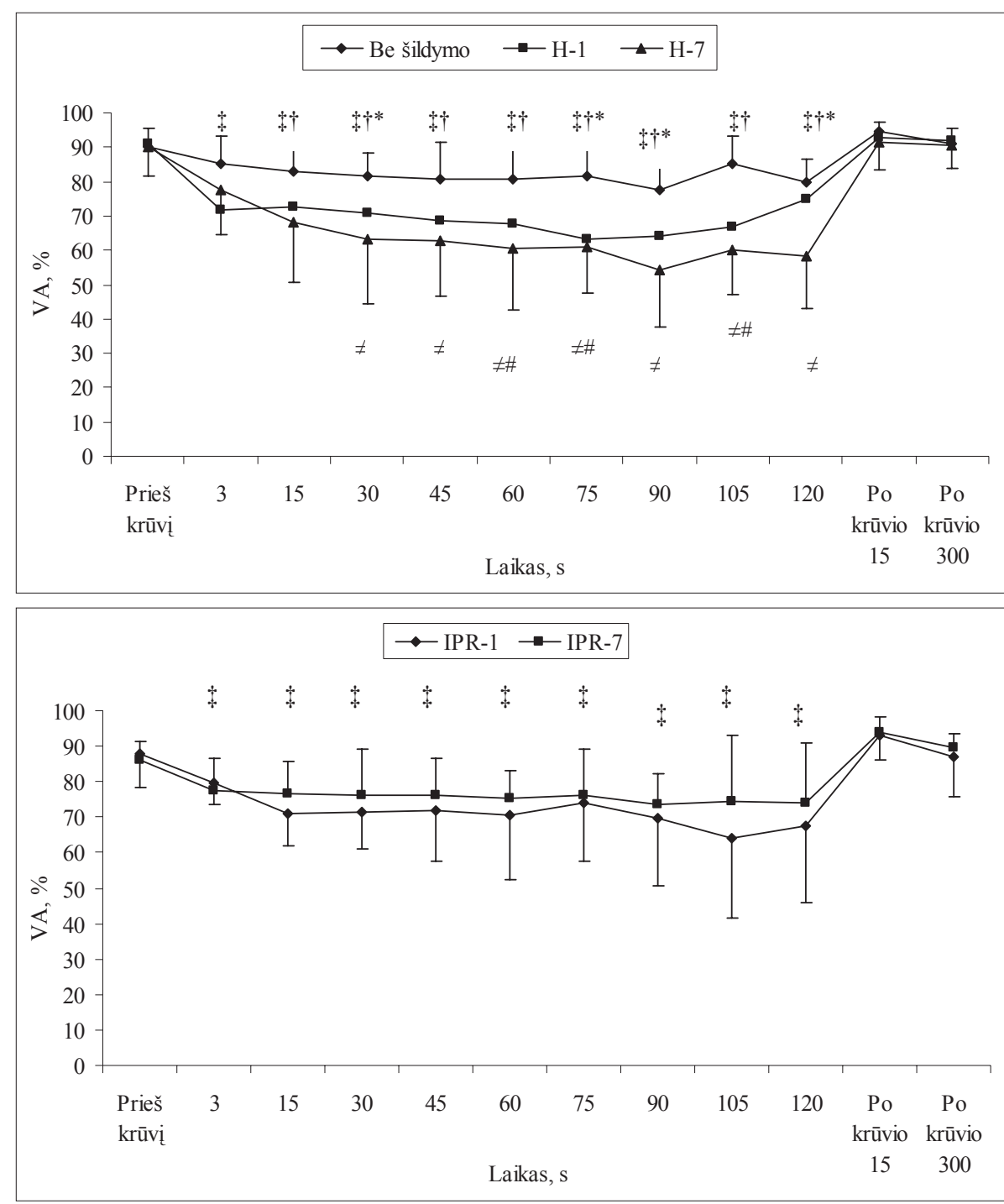

5 pav. Valingo aktyvavimo (VA, $\%$ ) rodikliai atliekant izometrini raumenų susitraukimą - tiesiant blauzdą per kelio sąnarị $120^{\circ}$ fiksuotu kampu
Pastaba. * - (kontrolinè); + - $\mathrm{H}-$ $1) ; \dagger-(\mathrm{H}-7)$ - skirtumas reikšmingas, lyginant su pradiniais rodikliais. \# - skirtumas reikšmingas tarp kontrolinio ir $\mathrm{H}-1$ rodiklio; $\neq-$ - skirtumas reikšmingas tarp kontrolinio ir H-7 rodiklio.

6 pav. Valingo aktyvavimo (VA, $\%)$ rodikliai atliekant izometrinị raumenụ susitraukimą — tiesiant blauzdą per kelio sąnarị $120^{\circ}$ fiksuotu kampu

\section{REZULTATŲ APTARIMAS}

Tyrimo metu nustatyta, kad septynis kartus kas antrą dieną pasyviai šildant kūną 45 minutes įmerkus kojas į vandeni, kurio temperatūra $44^{\circ} \mathrm{C}$, ir taikant MVJ-2 krūvî, organizmo aklimacija prie hipertermijos pasireiškè reikšmingu rektalinès temperatūros, šiluminio streso sumažèjimu ir netenkamo svorio, prilyginant kūno masei, padidejjimu. Organizmui prisitaikius prie hipertermijos, raumenu izometrinio susitraukimo jèga dar labiau sumažèjo atliekant MVJ-2 krūvị. Organizmo prisitaikymas prie hipertermijos padidino valingo aktyvavimo laipsni (centrini nuovargi), atliekant MVJ-2 krūvị.

Iki šiol literatūroje nepavyko rasti duomenu, rodančiuc, kokị termini poveiki patiria tiriamieji, taikant A. J. Sergeant (1987) pasiūlytą pasyvaus raumenų šildymo metodiką ir ar taikant ją kas antrą dieną dvi savaites iš eilès organizmas prisitaikys prie hipertermijos. Nustatyta, kad padidejjus ašinei kūno temperatūrai iki $38,7^{\circ} \mathrm{C}$ (vidutinio fizinio aktyvumo asmenu) ar $39,2^{\circ} \mathrm{C}$ (didelio meistriškumo asmenų) žmogus patiria kūno perkaitima, atsiranda valingu pastangu nuovargis (Cheung, McLellan, 1998). Panašia metodika vadovaudamiesi nustateme, kad tiriamosios patyrè hipertermiją rektalinè temperatūra vidutiniškai padidèdavo nuo $37,53 \pm 0,2$ iki $39,62 \pm 0,25^{\circ} \mathrm{C}(\mathrm{H}-1)$ ir nuo $37,23 \pm 0,16$ iki $39,25 \pm 0,3^{\circ} \mathrm{C}(\mathrm{H}-7)$, odos temperatūra - atitinkamai $10,12 \pm 0,16$ ir $9,65 \pm 4,53 \%$ ir viso kūno $-7,03 \pm 1,16$ ir $6,76 \pm 1,73 \%$. Be to, nustateme, kad H-7 pradinè temperatūra buvo reikšmingai mažesnè $(p<0,05)$, palyginus su H-1 pradine. Visgi vertinant temperatūros veiksni, rektalinès temperatūros reikšmingas sumažejimas septinto pasyvaus šildymo metu rodo organizmo prisitaikymą prie hipertermijos.

Hipertermijos metu vykstanti temperatūrinè homeostaze didina prakaitavimą, širdies ir kraujagysliu sistemos darbą (Armstrong, 2000). Nustatyta, kad dirbant karšto klimato sąlygomis ar atliekant didelio intensyvumo ilgos trukmès fizinius pratimus žmogus vidutiniškai netenka $0,8-1,41$ / h prakaito (Armstrong, 2000). Didžiausias nustatytas praran- 
damo prakaito kiekis - 3,71/ h (Armstrong, 1986). Aklimatizuoti žmonès kartu su prakaitu netenka apie $0,8-2,0 \mathrm{~g} \mathrm{NaCl} / 1$, o neaklimatizuoti apie $3,0-4,0 \mathrm{~g} \mathrm{NaCl} / 1$ (Armstrong, 2000). Pastarieji elektrolitai žmogaus organizme yra laikomi pagrindiniais, kurių dèka vyksta vandens toniškumo palaikymas viduląstelinèje ir tarpląstelinèje terpèje, nervinis laidumas, ląstelinis metabolizmas ir palaikomas kraujo tūris - osmoreguliacija ir spaudimas (Armstrong, 2000). Tyrimo metu nustatyta, kad tiriamosios vidutiniškai per valandą netekdavo apie $0,4 \pm 0,061 / \mathrm{h}(\mathrm{H}-1)$ ir 0,62 $\pm 0,121 / \mathrm{h}(\mathrm{H}-7)$, ir tai sudare atitinkamai apie $0,63 \pm 0,12$ ir $0,93 \pm 0,23 \%$ kūno masès. Taigi ívyko $\mathrm{I}^{\mathrm{o}}$ dehidratacija (skysčiu netekimas iki 2\% kūno masès). Dehidratacijos reikšmingas padidejjimas septinto eksperimento metu rodo, kad organizmas prisitaike prie hipertermijos. Šio tyrimo metu nenustateme $\mathrm{NaCl}$ kiekio, išskiriamo kartu su prakaitu. Vertindami organizmo širdies ir kraujagyslių sistemos (ŠKKS) prisitaikymą prie hipertermijos, nustatėme nereikšmingą širdies susitraukimo dažnio sumažejjimą septinto pasyvaus šildymo metu, kai pulsinio spaudimo kaita buvo labai panaši, lyginant su pirmu tyrimu. Todèl galima teigti, kad organizmo prisitaikymas prie hipertermijos neturèjo reikšmingo poveikio ŠKS.

Kitas svarbus rodiklis, rodantis organizmo aklimatizaciją — šiluminio streso indeksas, kuris yra išreikštas širdies kraujagyslių ir termoreguliacinès sistemų kaita pasyvaus šildymo metu. Septinto pasyvaus šildymo metu šiluminis stresas reikšmingai sumažèjo nuo 8,61 $\pm 1,17$ balų - H-1 (labai aukštas stresas) iki 7,31 $\pm 0,7$ balų — H-7 (aukštas stresas). Vertinant tiriamujų subjektyvų šilumini pojūtį ir komfortą, taip pat pastebimas rodikliu pagerejjimas, nors ir nereikšmingas. Šildymo metu vidutiniai šiluminio pojūčio ir komforto vertinimo rodikliai padidejo: $\mathrm{H}-1$ - nuo šilta ir patogu iki nepakeliamai karšta ir labai nepatogu, $\mathrm{H}-7$ - nuo šiek tiek šilta iki labai karšta ir nepatogu.

Septinto (H-7) eksperimentinio tyrimo metu nustatyta, kad organizmo prisitaikymas prie hipertermijos padidino maksimaliosios valingosios jègos nuovargi, atliekant MVJ-2 min, ir sukèlè mažesni valingo aktyvavimo laipsni, t. y. centrini nuovargi, lyginant su kontrolinio ir H-1 duomenimis. S. A. Morrison ir kt. (2004) atliktu tyrimų metu taip pat buvo nustatyta, kad hipertermija sumažina maksimaliają valingą jèga ir valingo aktyvumo laipsni. Manytume, kad pastarieji rodikliai galèjo pablogèti dèl padidejusio organizmo prakaitavimo, kurio metu išskiriamas prakaitas labiau vėsino kūno paviršiuc, ir tai lėmè rektalinès temperatūros, šiluminio streso bei širdies susitraukimo dažnio sumažèjima, tačiau didesni druskų bei elektrolitų netekimą. Septynis kartus taikant hipertermiją sukelianti metoda, organizmas aklimatizavosi sukeldamas dar didesni centrini nuovargi ir valingosios jègos sumažèjimą.

\section{IŠVADOS}

1. Septynis kartus kas antrą dieną taikant pasyvu šildymą, organizmo prisitaikymą prie hipertermijos parodè reikšmingas rektalinès temperatūros, šiluminio streso sumažèjimas ir netenkamo svorio, lyginant su kūno mase, padidejimas.

2. Aklimatizavus organizmą prie hipertermijos, raumenų izometrinio susitraukimo jèga dar labiau sumažèjo taikant MVJ-2 krūvị.

3. Organizmo aklimacija hipertermijai padidino valingo aktyvavimo laipsni (centrini nuovargi) taikant MVJ-2 krūvị.

\section{LITERATŪRA}

Armstrong, L. E., Marech, C. M. (1991). The induction and decay of heat acclimatisation in trained athletes. Sports Medicine, 12, 302-312.

Armstrong, L. E. (2000). Performing in Extreme Environments: The Importance of Dietary Sodium. Human kinetics. P. $38-45$.

Brazaitis, M., Skurvydas, A., Ramanauskienė, I., Masiulis, N. (2004). Skirtingos temperatūros poveikis keturgalvio šlaunies raumens nuovargiui ir atsigavimui, esant nevalingam izometriniam raumens susitraukimui. Ugdymas. Kūno kultūra. Sportas, 4 (54), 32-39.

Cheung, S. S. (2007). Hyperthermia and voluntary exhaustion: Integrating models and future chalanges. Review. $\mathrm{Ap}$ plied Physiology Nutritional Metabolism, 32, 808-817.

Cheung, S. S., Mclellan, T. M. (1998). Comparison of short-term aerobic training and high aerobic power on tolerance to uncompensable heat stress. Aviation, Space, and Environmental Medicine, 70 (7), 637-643.

Gagge, A. P, Stolwijk, J. A, Hardy, J. D. (1967). Comfort and thermal sensations and associated physiological responses at various ambient temperatures. Environmental Research, 1, 1-20.

Gonzalez-Alonso, J., Teller, C., Andersen, S. L. et al. (1999). Influence of body temperature on the development of fatigue during prolonged exercise in the heat. Journal of Applied Physiology, 86, 1032-1039.

Kang, B. S., Song, S. H., Suh, C. S., Hong, S. K. (2003). Changes in body temperature and basal metabolic rate of the Ama 1963. Wilderness Environmental Medicine, 14 (3), $193-197$.

Kèvalaitis, E., Illert, M., Hultborn, H. (2002). Žmogaus fiziologija. Kaunas: KMU.

MacDougall, J. D. Reddan, W. G. Layton, C. R., Dempsey, J. A. (1974). Effect of metabolic hyperthermia on performance during heavy prolonged exercise. Journal of Applied Physiology, 36, 538-544.

Moran, D. S., Shitzer, A., Pandolf, K. B. (1998). A physiological strain index to evaluate heat stress. Ambient 
Journal of Physiology, 275, R 129-134.

Morrison, S. A., Sleivert, G. G., Cheung, S. S. (2004). Passive hyperthermia reduces voluntary activation and isometric force production. European Journal of Applied Physiology, 91, 729-736.

Nielsen, B. (1992). Heat stress causes fatigue! Exercise performance during acute and repeated exposure to hot, dry environments. Medicine and Sport Science, 34, 207-217.

Nybo, L., Nielsen, B. (2001). Hyperthermia and central fatigue during prolonged exercise in humans. Journal of Applied Physiology, 91, 1055-1060.

Proulx, C. I., Ducharme, M. B., Kenny, G. P. (2003). Effect of water temperature on cooling efficiency during Hyperthermia in humans. Journal of Applied Physiology, 94, 1317-1323.

Ramanauskienė, I., Skurvydas, A., Brazaitis, M. ir kt. (2006). Moteru ir vyrų kelio tiesiamujų ir lenkiamujų raumenų susitraukimo funkcijos priklausomybè nuo temperatūros.
Ugdymas. Kūno kultūra. Sportas, 3 (63), 49-54.

Sargeant, A. J. (1987). Effect of muscle on leg extension force and short-term power output in humans. European Journal of Applied Physiology, 56, 693-698.

Thomas, M. M., Cheung, S. S., Elder, G. C., Sleivert, G. G. (2006). Voluntary muscle activation is impaired by core temperature rather than local muscle temperature. Journal Applied Physiology, 100 (4), 1361-1369.

Todd, G., Butler J. E., Taylor, J. L., Gandevia, S. C. (2005). Hyperthermia: A failure of the motor cortex and the muscle. Journal of Physiology, 563 (2), 621-631.

Vadopalas, K., Skurvydas, A., Brazaitis, M. et al. (2007). Impact of hyperthermia and dehydration on skeletal muscle of adult women performing isometric exercise of maximum intensity. Ugdymas. Kūno kultūra. Sportas, 3 (66), 48-55.

Wilmore, J. H, Costill, D. L. (2004). Physiology of Sport and Exercise. Hong Kong, China: Champaign Human Kinetics.

\title{
ADAPTATION OF HUMAN MOTOR SYSTEM TO HYPERTHERMIA
}

\author{
Ieva Lukošiūtè-Stanikūnienė, Marius Brazaitis, Albertas Skurvydas, Soneta Ivanonė, \\ Dalia Mickevičienė, Irena Vitkienė \\ Lithuanian Academy of Physical Education, Kaunas, Lithuania
}

\begin{abstract}
Research aim was to define how human motor system adapts to hyperthermia. The study group were healthy and physically active women $(\mathrm{n}=6)$. Their age was $22.2 \pm 3.4$ years, body mass $-63.93 \pm 6.74 \mathrm{~kg}$, height $167.6 \pm 7.2 \mathrm{~cm}$. There were two studies performed — the control study and the experimental study. The experimental study differed from the control one because during it hyperthermia was passively induced instead of warm-up (the study group kept feet in the warm bath with water, the temperature of which was $44 \pm 1^{\circ} \mathrm{C}$, sitting for 45 minutes). After the bath but no later than within 5 minutes the participants were asked to sit on a special dynamometer chair and perform a two-minute maximal voluntary isometric muscle contraction (MVJ-2 min). The control test was performed prior to the load, and 15 and $300 \mathrm{~s}$ after the load the muscle was stimulated by TT $100 \mathrm{~Hz}$ (duration of stimulation $-250 \mathrm{~ms}$, frequency $-100 \mathrm{~Hz}$ ). Research with one subject lasted for 14 days (the same experimental protocol was applied 7 times every other day).

After passive heating, the rectal temperature increased by $2.08 \pm 0.24^{\circ} \mathrm{C}(\mathrm{p}<0.05)$ on average. We also found that the rectal temperature before heating was significantly lower during the $7^{\text {th }}$ heating in comparison with the $1^{\text {st }}$ heating. The subject lost $\mathrm{H}-1-0.63 \pm 0.12 \%$, and $\mathrm{H}-7-0.98 \pm 0.23 \%$ on average of the body mass during the hyperthermia $(p<0.01)$. It shows that the subjects more sweated off during the $7^{\text {th }}$ heating in comparison with the $1^{\text {st }}$ heating. Physiological stress index (10 point system) showed that subjects underwent very high physiological stress $-8.61 \pm 1.17$ after the $1^{\text {st }}$ heating and high $-7.31 \pm 0.71$ after the $7^{\text {th }}$ heating.

We determined that the thermal sensation and comfort at the $35^{\text {th }}$ heating minute during the $1^{\text {st }}$ heating reached from warm and comfortable to unbearably hot and very uncomfortable $(\mathrm{p}<0.05)$, and during the $7^{\text {th }}$ heating from a little warm and comfortable to hot and uncomfortable $(\mathrm{p}<0.05)$.

The results showed that the force of muscle contraction started decreasing at the $3^{\text {rd }} \mathrm{s}$ of MVC- $2 \mathrm{~min}$ load during the $1^{\text {st }}$ heating and $15^{\text {th }} \mathrm{s}$ - during the $7^{\text {th }}$ heating $(\mathrm{p}<0.05)$. This significant difference remained for $15 \mathrm{~s}$ after load. The force of muscle isomeric contraction recovered 5 min after the load $(\mathrm{p}>0.05)$. We also determined that the voluntary activation level was significantly lower during the $1^{\text {st }}$ and the $7^{\text {th }}$ heating in comparison with the control test $(\mathrm{p}<0.05)$.

Generally our study showed that fatigue after hyperthermia was increased by two main determinants — the local changes of the muscle and the changes in the central nervous system. Passive thermal heating applied seven times every other day improved physiological and psychological tolerance to increased temperature.
\end{abstract}

Keywords: hyperthermia, acclimation, central fatigue, isometric exercises.

Gauta 2008 m. spalio 3 d.

Received on October 3, 2008

Priimta 2008 m. gruodžio 9 d.

Accepted on December 9, 2008
Ieva Lukošiūtè-Stanikūnienè

Lietuvos kūno kultūros akademija

(Lithuanian Academy of Physical Education)

Sporto g. 6, LT-44221 Kaunas

Lietuva (Lithuania)

Tel +370 37302677

E-mail ieva.lukosiute@antidopingas.lt 